\title{
PENGARUH KAFEIN TERHADAP LENGKUNG EKOR SPERMATOZOA EPIDIDIMIS SAPI BALI
}

\author{
Oktora Dwi Putranti \\ Program Studi Peternakan Fakultas Pertanian.Universitas Kkairun, Ternate. \\ Email: oktora.unkhair@gmail.com
}

\begin{abstract}
This study aims to analyze the influence of caffeine on the distance of the tail movement of the spermatozoa epididymis cattle Bali. Methods in this study with a collection of sperm from Slaughter House (RPH) and then conducted the process of freezing with Tris yolk dilution. Treatment of caffeine with levels of $0 \mathrm{mg} / \mathrm{ml}, 2$ $\mathrm{mg} / \mathrm{ml}, 4 \mathrm{mg} / \mathrm{ml}$ and $6 \mathrm{mg} / \mathrm{ml}$ in spermatozoa that have been in thawing. The variables observed were DCL, DAP, DSL, ALH analyzed by CASA. Results showed no difference $(P>0.05)$ motility with caffeine treatment and short sperm tailwave distance of $37.27 \mu \mathrm{m}$ showed the sperm motility velocity.
\end{abstract}

Keywords: spermatozoa tail, caffeine

\section{PENDAHULUAN}

Rumah potong hewan (RPH) merupakan tempat untuk mendapatkan daging atau karkas dari ternak yang di potong, namun yang tidak pernah disadari adalah RPH juga memiliki fungsi yang lain yaitu tersedianya sumber daya genetik. Testis merupakan tempat penghasil sperma dimana setiap ternak yang dipotong di RPH memiliki kualitas yang baik yaitu performan yang baik, tidak cacat, sapi telah dewasa yang akan berpengaruh positif terhadap kualitas sperma.

Ternak yang telah dipotong tentu saja akan mengalami penurunan energi untuk metabolisme dan gerak, hal ini tentu saja berpengaruh terhadap kualitas sperma. Adenosin triphosphate (ATP) adalah sumber energi yang di butuhkan sperma untuk motil. Ketersediaan ATP dalam testis juga sangat berkaitan pasca ternak dipotong, untuk itu penanganan sperma harus segera mungkin dilakukan sebelum energi (ATP) habis yang ditandai fase regormortis postmortem (PTM) selesai (Sutardi,1987 dalam Gumilar, 2011).

Pembekuan semen adalah metode yang tepat untuk menyelamatkan sperma kauda epididimis. Semen beku memiliki banyak manfaat salah satunya dapat digunakan pada waktu yang tidak terbatas, namun juga memiliki kekurangan yaitu penurunan motilitas dan viabiltas. Masalah tersebut dapat diatasi dengan penambahan kafein pada pengencer sperma pasca tahawing. Kafein memiliki mekanisme dapat menstimuli pelepasan $\mathrm{Ca} 2+$ dan blockade phoshodiesterase (Lamarine, 1998). Mekanisme tersebut sangat penting pada sperma karena dengan fluktuasi $\mathrm{Ca}+$ yang stabil akan mampu menjaga stabilitas membran yang berdapak positif dalam kelangsungan metabolisme. Kandungan fosfhat dalam sperma sangat rendah dengan adanya blockade ini dapat meningkatkan fhosfhate sehingga energi ATP yang dihasilkan dapat meningkat, dengan demikian akan merangsang gerakan sperma.

Motilitas terjadi karena adanya pergerakan seluruh bagian sperma yang dimulai dari midepiece kemudian merangsang endpiece dan kepala sperma ikut bergerak mengikuti pergerakan dari ekor. Gerakan sperma tersebut dapat dilihat dengan computerized assisted sperm analyzed (CASA).

\section{METODE PENELITIAN}

Sperma yang dikoleksi di RPH dibawa ke laboraturium untuk diproses selanjutnya menjadi semen beku. Unit Rehabilitasi 
Agrisaintifika

Jurnal Ilmu-Ilmu Pertanian

Vol. 2, No. 2, 2018

Putranti, 2018

Reproduksi (URR) Departement Klinik Reproduksi dan Patologi (KRP) IPB sebagai tempat proses semen beku dan analisis CASA dilaksanakan di laboratorium reproduksi, pemuliaan dan kultur sel hewan, Puslit Bioteknologi LIPI Cibinong.

Analisis motilitas sperma dengan cara straw dithawing pada suhu $38^{\circ} \mathrm{C}$, sentrifus dengan $1800 \mathrm{rpm}$ selama 5 menit, kemudian hisap dengan mikropipet sampai batas endapan sperma, beri perlakuan tris kafein dengan level $0 \mathrm{mg} / \mathrm{ml}, 2 \mathrm{mg} / \mathrm{ml}, 4 \mathrm{mg} / \mathrm{ml}$ dan 6 $\mathrm{mg} / \mathrm{ml}$, dengan perbadingan $1: 10 \mu \mathrm{l}$. Ambil 1 $\mu \mathrm{l}$ sperma teteskan dalam gelas objek tutup dengan cover glass dan dilihat menggunakan CASA.

\section{Rancangan penelitian}

Penelitian ini menggunakan Rancangan Acak Lengkap (RAL) dengan 4 perlakuan kafein yaitu T0 $(0 \mathrm{mg} / \mathrm{ml})$, T2 $(2 \mathrm{mg} / \mathrm{ml})$, T4 $(4 \mathrm{mg} / \mathrm{ml})$ dan T6 $(6 \mathrm{mg} / \mathrm{ml})$ dengan 4 kali ulangan. Data yang diperoleh dianalisis dengan analisis of variance (ANOVA) satu arah, apabila terdapat perbedaan yang nyata $(P<0,05)$ atau sangat nyata $(P<0,01)$, dilanjutkan uji Tukey-W-
Procedure dengaan SPSS 18 (Trihendradi, 2010).

\section{HASIL DAN PEMBAHASAN}

Motilitas merupakan faktor yang penting dalam penilaian kualitas sperma. fertilisasi dapat terjadi karena sperma mampu berenang menunju sel telur. Hasil analisis perlauan kafein pada sperma kauda epididimis sapi Bali pasca thawing menggunakan CASA dapat dilihat pada tabel 1 .

Perlakuan kafein akan dapat meningkatkan pergerakan dari sperma diam menjadi simetris. Lengkungan ekor sebagai akibat adanya energi adenosine triphosphate (ATP), sehingga penilaian gerakan sel sperma menjadi sangat penting dalam kualitas sperma. Distance average path (DAP) adalah jarak rata-rata garis sperma, distance curved line (DCL) merupakan jarak garis lengkung pada bagian ekor, distance straight line (DSL) yaitu jarak garis lurus ekor dan amplitude of lateral head displacement (ALH) adalah amplitudo perpindahan menyamping kepala sperma (Toman et al., 2008).

Tabel 1. Panjang gerakan sperma dengan perlakuan kafein pada sperma kauda epididimis sapi Bali pasca thawing menggunakan CASA (rerata + SD)

\begin{tabular}{ccccc}
\hline \multirow{2}{*}{$\begin{array}{c}\text { Parameter } \\
(\mu \mathrm{m})\end{array}$} & \multicolumn{4}{c}{ Perlakuan } \\
\cline { 2 - 5 } & $\mathrm{P} 0$ & $\mathrm{P} 2$ & $\mathrm{P} 4$ & $\mathrm{P} 6$ \\
\hline $\mathrm{DCL}$ & $38,20 \pm 2,08$ & $37,27 \pm 1,56$ & $39,64 \pm 5,91$ & $40,10 \pm 0,98$ \\
DAP & $18,16 \pm 0,84$ & $20,00 \pm 1,40$ & $18,58 \pm 0,96$ & $17,61 \pm 1,36$ \\
DSL & $13,01 \pm 1,11$ & $14,70 \pm 1,77$ & $13,76 \pm 0,42$ & $13,13 \pm 1,07$ \\
ALH & $3,33 \pm 0,48$ & $3,55 \pm 0,76$ & $3,63 \pm 0,25$ & $3,14 \pm 0,53$ \\
\hline
\end{tabular}

Keterangan: tidak adanya supersrib pada baris yan sama menunjukkan tidak ada perbedaan $(P>0,05)$. $P 0: 0$ $\mathrm{mg} / \mathrm{ml}$ ), P2 : $2 \mathrm{mg} / \mathrm{ml}$ ), P4 : $4 \mathrm{mg} / \mathrm{ml}$ ) dan T6 : $6 \mathrm{mg} / \mathrm{ml}$. DAP: jarak rata-rata, DCL: jarak garis lengkung, DSL: jarak garis lurus, ALH : amplitudo perpindahan kepala. 
Hasil tabel 1 menunjukkan perlakuan kafein tidak berpengaruh $(P>0,05)$ terhadap DCL, DAP, DSL dan ALH. Jarak lengung ekor sperma bergerak motil terjauh pada P6 $(40,10$ $\pm 0,98 \mu \mathrm{m})$, diikuti P4 $(39,64 \pm 5,91 \mu \mathrm{m})$, P0 $(38,20 \pm 2,08 \mu \mathrm{m})$ dan P2 $(37,27 \pm 1,56 \mu \mathrm{m})$. Nilai jarak lengkung yang semakin kecil menunjukkan gerakan semakin cepat dibandingkan dengan nilai jarak lengkung yang semakin jauh. Nilai tersebut menunjukkan semakin tinggi level kafein gerakan sperma lambat, hal ini dapat disebabkan rendahnya energi yang tersedia untuk motilitas.

Distance average path (DAP) sperma memiliki nilai jarak pada P2 $(20,00 \pm 1,40$ $\mu \mathrm{m})$, kemudian P4 $(18,58 \pm 0,96 \mu \mathrm{m}), \mathrm{P} 0$ $(18,16 \pm 0,84 \mu \mathrm{m})$ dan yang terakhir P6 $(18,16 \pm 0,84 \mu \mathrm{m})$. Jarak ini merupakan garis ukuran sperma saat motil. Nilai tersebut sesuai dengan nilai DCL dimana semakin renggang maka nilai DAP semakin kecil. Hal ini menggambarkan bahwa saat sperma bergerak ukuran ekor membentuk satu bukit sangat berpengaruh terhadap jarak dari pangkal kepala sampai lengkungan ekor sperma.

Perlakuan kafein pada distance straight line (DSL) menunjukkan rerata P2 (14,70 \pm $1,77 \mu \mathrm{m}), \mathrm{P} 4(13,76 \pm 0,42 \mu \mathrm{m}), \mathrm{P} 6(13,13 \pm$ $1,07 \mu \mathrm{m})$ dan P0 $(13,01 \pm 1,11 \mu \mathrm{m})$. Hasil tersebut merupakan jarak lurus pada satu gelombang ekor, yang menunjukkan bahwa perlakuan kafein pada level yang semakin meningkat akan memiliki garis lurus yang pendek. Hal ini dapat terjadi karena semakin tinggi kafein menyebabkan rusaknya integritas membran sehingga terjadi penyusutan panjang ekor sperma yang berpengaruh terhadap panjang garis lurus satu gelombang ekor.
Amplitude of lateral head displacement (ALH) adalah lebar perpindahan menyamping kepala sperma, diperoleh hasil P4 (3,63 \pm $0,25 \mu \mathrm{m}), \mathrm{P} 2(3,55 \pm 0,76 \mu \mathrm{m}), \mathrm{P} 0(3,33 \pm$ $0,48 \mu \mathrm{m})$ dan P6 $(3,14 \pm 0,53 \mu \mathrm{m})$. Hal tersebut menunjukkan bahwa kafein $6 \mathrm{mg} / \mathrm{ml}$ memiliki pergerakan yang lambat, yang ditunjukkan dengan gerakan ekor yang lemah akan berkorelasi terhadap pergerakan kepala sperma.

\section{KESIMPULAN}

Perlakuan kafein pada sperma kauda epididimis sapi Bali pasca thawing dengan CASA diperoleh hasil tidak berpengaruh terhadap ukuran gelombang gerakan ekor sperma.

\section{DAFTAR PUSTAKA}

Toman, R. H. Hluchy, S. Massanyi, P. Siska, B. Lukac, N. Slivkova, J. Golian, J. Cupka, P. 2008. Computer-Assisted Semen Analysis Of Rat Spermatozoa After An Intraperitoneal Administration Of Insectidie Diazinon. Lucari Stiintifice Zootehnie Si Biotehnologii. Vol 41 (1): 802-806.

Gumilar, J. 2011. Pengaruh Berbagai Jenis Daging (Ayam, Babi dan Sapi) dan Fase Postmortem (Pada Daging Babi) Terhadap Kualitas dan Mikrostruktur Surimi (Surimi Like Material/SLM). Karya IImiah Universitas Padjadjaran, Bandung.

Lamarine, R. J. 1998. Caffeine As An Ergogenic Aid. In Spiller: Caffeien. Healt Reserth and Studies Center and Sphera Foundation. Los Altos, California. CRC Press.

Trihendradi, C. 2010. Step by Step SPSS 18 Analisis Data Statistik. Andy Offset. Yogyakarta. 